\title{
CONNECTION BETWEEN BODY POSTURE INDICATORS AND DOMINANT HAND WITH SCOLIOTIC BODY POSTURE IN HANDBALL PLAYERS
}

\author{
POVEZANOST IZMEĐU \\ POKAZATELJA DRŽANJA \\ TIJELA I DOMINANTNE RUKE \\ SA SKOLIOTIČNIM TJELESNIM \\ DRŽANJEM KOD RUKOMETAŠA
}

\begin{abstract}
The modern way of life is the cause of the increasing occurrence of improper body posture in children and adolescents. In athletes, improper body posture can lead to numerous chronic health problems and injuries that affect their performance in sports. The handball game is characterized by dynamism and mobility, with constant and rapid changes of body positions and technique elements. Due to certain characteristics of handball as a sport (parts of the technique that are asymmetric due to playing with one hand) there is a reasonable doubt that handball players are exposed to factors that can cause a development of postural deformities. The aim of the study is to investigate whether scoliotic posture is a frequent occurrence in adolescents who train handball, and whether there is a correlation between the relevant indicators of improper body posture and the dominant hand with scoliotic body posture in handball players. The study was conducted on a sample of 98 adolescents aged 13-18 who had been involved in the training process for over three years and were tested with clinical Adams forward bend test. A posterior examination was used to determine the types of body posture. The sample of variables for the assessment of body posture contained numerical values of eight reference points in the posterior examination. To determine the differences between groups in variables of the questionnaire, and in determining the difference between the respondents in the variables obtained from the questionnaire, the Chi-square test was used, and a contingency table with frequencies and percentages was determined. A significant difference was found between right-sided and normal body posture, where right-sided posture subjects spent significantly more years training a handball compared to those with normal body posture, which suggests that this sport can be associated with the occurrence of a scoliotic posture.
\end{abstract}

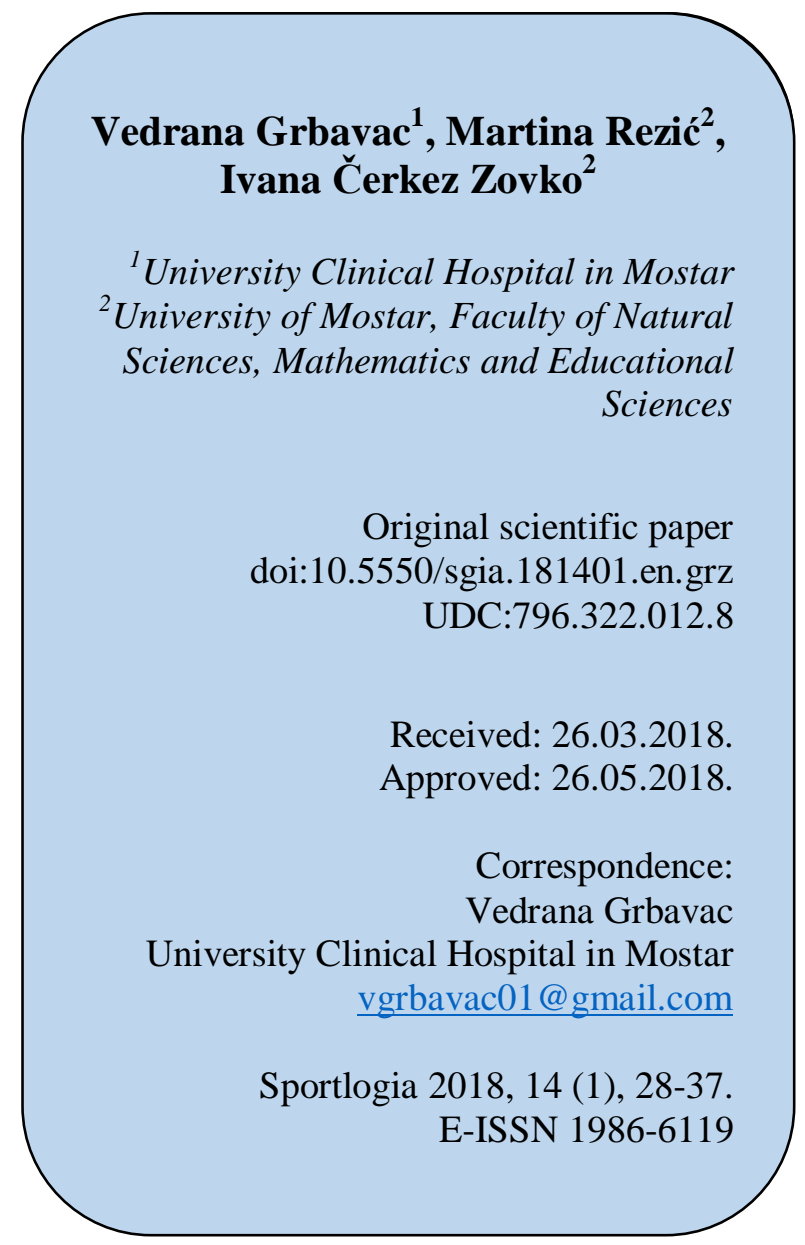

Key words: body posture, dominant hand, scoliotic posture, handball.

Grbavac, V., Rezić, M., \& Zovko, I. Č. (2018). Connection between body posture indicators and dominant hand with scoliotic body posture in handball players. Sportlogia, 14 (1), 28-37. doi:10.5550/sgia.181401.en.grz

Page 28. 


\section{INTRODUCTION}

The problem of today is hypokinesia (a state of reduced motion) that leads to uneven development of individual muscle groups. Neglected paramorphisms, especially during the developmental period, may lead to dysmorphisms that require long-term and painful treatment. Incorrect body postures resulting from the weakened structure of postural muscles that have been identified during growth and development, and especially those detected at an early age, can be corrected by additional physical exercise programs. Early, i.e. timely diagnosis is the most important element of successful treatment (Paušić, 2007). Although, generally speaking, it is clear that physical activity has multiple positive effects on certain organ systems and human organisms as a whole, however, doctors of sports medicine point to an increased incidence of improper posture and deformities in those who are actively involved in sports activities (Kosinac, 2002). Professional sport has its negativities, and most of these negativities can be reflected on the health of athletes.

Handball is a sport of complex polystructural movements in which there are a whole range of different moves (a step, a cross step ...), jumps (smash, block, shot ...), throws and falls (dive, rolling ...) static planks in positions, hits (Jankovic, Marelić and Jankovic, 2003). The technical elements of handball, which are asymmetrical due to one-handed performance, point to the likelihood that handball players are exposed to factors that may cause postural deformities. The asymmetric load in combination with a large number of jumps and landings on hard surfaces can have a very negative impact on the locomotor apparatus. Rapid growth in the adolescent growth momentum and the inability of the musculoskeletal system to overcome these sudden changes leads to irregular body postures (scoliosis, kyphosis, lordosis). Since irregular body postures can take on different forms, these forms are defined by various authors through the types of body postures (Aagaard and Jørgensen, 1996). The literature does not offer a large number of papers that investigate the scoliotic posture and its connection with sport, especially handball. The results of this research aim to show the special features of the handball and its connection with the scoliotic posture. The aim of the study is to investigate whether scoliosis is a frequent occurrence in adolescents who train handball, and whether there is a correlation between the relevant indicators of improper posture and the dominant hand with scoliotic body posture in handball players.

\section{METHODS}

The research was carried out on a sample of 98 male adolescents who practice handball in the handball club "MI Izvidjac" Ljubuski. All athletes aged 13-18, who had been involved in the training process for over three years, were tested with the clinical Adams forward bend test (Theologis, Fairbank, Turner-Smith, and Pantayopoulos, 1997). After a forward bend test, an estimate using a plummet was performed to estimate spine deviations in the frontal plane and anthropological measurements by which the data on the bilateral difference was obtained. A posterior examination was used to determine the types of body postures. The sample of variables for the assessment of body posture contains numerical values of eight reference points in the posterior examination (Pausic, 2007). Determination of body posture types was made using a plummet with the photographs of each respondent in order to obtain the most objective result. 
Indicators of body posture in the posterior examination:

- PUHO - by placing markings on the upper edge of the left and right ear, one can determine a deviation of the line connecting two markings from the horizontal in degrees and centimeters if the left side is lowered (-) if the left side is raised (+)

- PRAM - by setting markings to the highest top of the left and right shoulders: acromion, it is possible to determine a deviation of the line connecting two markings from the horizontal in degrees and centimeters if the left side is lowered (-) if the left side is raised $(+)$

- PLOPG - by setting markings on the left and right angulus of superior blades, it is possible to determine a deviation of the line connecting two markings from the horizontal in degrees and centimeters if the left side is lowered (-), if the left side is raised (+)

- PLOPD - by setting markings on the left and right angulus of inferior blades, it is possible to determine a deviation of the line connecting two markings from the horizontal in degrees and centimeters, if the left side is lowered (-), if the left side is raised (+)

- PZDJ - by setting markings on the left and right spina illiacu superior posterior, it is possible to determine a deviation of the line connecting two markings from the horizontal in degrees and centimeters, if the left side is lowered (-), if the left side is raised $(+)$

- PKOL - by setting markings on the left and right epicondylus medialis, it is possible to determine a deviation of the line connecting two markings from the horizontal in degrees and centimeters, if the left side is lowered (-), if the left side is raised (+)

- PNZG - by setting markings on the left and right malleolus medialis, it is possible to determine a deviation of the line that connects the two markings from the horizontal in degrees and centimeters, if the left side is lowered (-), if the left side is raised (+).

- PKRALJ - by setting markings to processus spinosus vertebrae, it is possible to determine a deviation of the line linking the vertebrae markings with the line of the plummet, if the spine deviation is to the left (-), if the spine deviation is to the right $(+)$. 


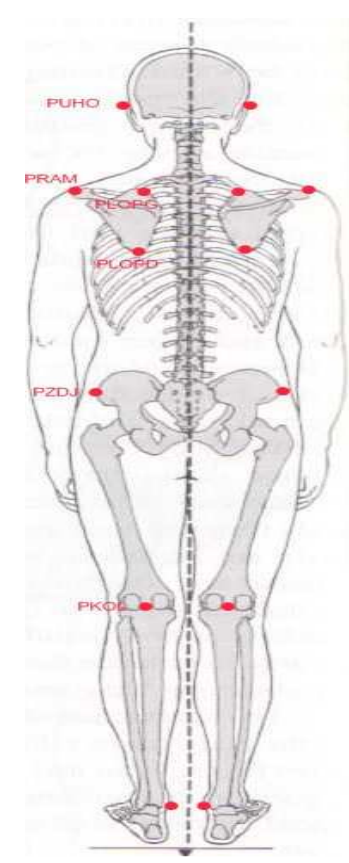

Figure 1 - Reference points in posterior examination of body posture (17)

Processing of data that was collected by the said experimental procedure was done for each class separately (by age), and all data was processed with Statistica 7 statistical set (StatSoft, USA), and SPSS 16 (USA).

K-means method of cluster (taxonomic) analysis (Hartigan, 1978) was used to determine the types of body postures, which is used to determine the number of groups of maximally different subjects, and by means of which using the analysis of the variance the differences between the groups in each indicator can be determined. This method allows defining a number of groups independently.The following parameters are used in this method: descriptive parameters: arithmetic mean (AS) and standard deviation (SD), variance analysis indicators ( $F$ - value, $\mathrm{p}$ - level of significance), number of respondents in each group, membership of the respondents to a particular group.

To determine the differences between groups in variables of the questionnaires, and in determining the difference between the respondents in the variables obtained from the questionnaire, a Chi-square test was used, and a contingency table with frequencies and percentages was determined.

\section{RESULTS}

In this chapter, the results of research work that correspond to the set goals are presented. Below is the data obtained by statistical processing. By means of analyzes, the respondents were divided into three groups based on the type of body posture that statistically significantly differed.

Table 2 - Body posture type

\begin{tabular}{|l|c|c|}
\hline Type of body posture & Number of respondents & Percentage \% \\
\hline Left-sided scoliotic posture & 16 & 16,3 \\
\hline Normal body posture & 34 & 34,7 \\
\hline Right-sided scoliotic posture & 48 & 49,0 \\
\hline Total & 98 & 100 \\
\hline
\end{tabular}

Grbavac, V., Rezić, M., \& Zovko, I. Č. (2018). Connection between body posture indicators and dominant hand with scoliotic body posture in handball players. Sportlogia, 14 (1), 28-37. doi:10.5550/sgia.181401.en.grz

Page 31. 
In the examined sample, respondents with right-sided scoliotic posture were the most present $\left(\chi^{2}\right.$ test $\left.=15,755 ; \mathrm{df}=2 ; \mathrm{P}<0,001\right)$.

Table 3 - Overview of right-handed and left-handed persons in relation to type of body posture

\begin{tabular}{|r|c|c|c|c|c|}
\hline \multicolumn{2}{|c|}{ Dominant hand } & \multicolumn{3}{c|}{ Type of body posture } & \multirow{2}{*}{ Total } \\
\cline { 3 - 6 } & Left-sided & Normal & Right-sided & Count \\
\hline \multirow{2}{*}{ Right } & 12 & 31 & 46 & 89 \\
\cline { 2 - 6 } & $\%$ within Type of posture & $75,0 \%$ & $91,2 \%$ & $95,8 \%$ & $90,8 \%$ \\
\hline \multirow{2}{*}{ Left } & Count & 4 & 3 & 2 & 9 \\
\cline { 2 - 6 } & $\%$ within Type of posture & $25,0 \%$ & $8,8 \%$ & $4,2 \%$ & $9,2 \%$ \\
\hline \multirow{2}{*}{ Total } & Count & 16 & 34 & 48 & 98 \\
\cline { 2 - 6 } & $\%$ within Type of posture & $100,0 \%$ & $100,0 \%$ & $100,0 \%$ & $100,0 \%$ \\
\hline
\end{tabular}

Respondents with the dominant right hand had significantly more often a right-handed scoliotic posture than those with dominant left hand $\left(\chi^{2}\right.$ test $\left.=6,253 ; \mathrm{df}=2 ; \mathrm{P}=0,044\right)$. Leftsided scoliotic posture was determined in 16 respondents, of which $12(75.0 \%)$ were righthanded, $4(25.0 \%)$ were left-handed. Normal body posture was shown by 34 subjects, of whom $31(91.2 \%)$ had a dominant right hand, and $3(8.8 \%)$ were left-handed respondents. Right-sided scoliotic posture was demonstrated in 48 respondents, consisting of $46(95.8 \%)$ right-handed and $2(4.2 \%)$ left-handed.

Table 11 - Overview of positions of players and the type of body posture

\begin{tabular}{|c|c|c|c|c|c|}
\hline \multirow{2}{*}{\multicolumn{2}{|c|}{ Player position }} & \multicolumn{3}{|c|}{ Type of posture } & \multirow{3}{*}{\begin{tabular}{|l|} 
Total \\
8
\end{tabular}} \\
\hline & & \multirow{2}{*}{\begin{tabular}{|l} 
Left-sided \\
2
\end{tabular}} & \multirow{2}{*}{$\frac{\text { Normal }}{2}$} & \multirow{2}{*}{\begin{tabular}{|l|}
$\begin{array}{c}\text { Right- } \\
\text { sided }\end{array}$ \\
4
\end{tabular}} & \\
\hline Right back & Count \% within & & & & \\
\hline & Type of posture & $12,6 \%$ & $5,9 \%$ & $8,4 \%$ & $8,2 \%$ \\
\hline \multirow[t]{2}{*}{ Right wing } & Count \% within & 5 & 3 & 3 & 11 \\
\hline & Type of posture & $31,3 \%$ & $8,8 \%$ & $6,3 \%$ & $10,2 \%$ \\
\hline \multirow[t]{2}{*}{ Goalkeeper } & Count $\%$ within & 0 & 6 & 9 & 15 \\
\hline & Type of posture & $0,0 \%$ & $17,6 \%$ & $18,8 \%$ & $15,3 \%$ \\
\hline \multirow[t]{2}{*}{ Left back } & Count $\%$ within & 1 & 5 & 4 & 10 \\
\hline & Type of posture & $6,3 \%$ & $14,7 \%$ & $8,3 \%$ & $10,2 \%$ \\
\hline \multirow[t]{2}{*}{ Left wing } & Count $\%$ within & 3 & 4 & 16 & 23 \\
\hline & Type of posture & $18,8 \%$ & $11,8 \%$ & $33,3 \%$ & $23,5 \%$ \\
\hline
\end{tabular}

Grbavac, V., Rezić, M., \& Zovko, I. Č. (2018). Connection between body posture indicators and dominant hand with scoliotic body posture in handball players. Sportlogia, 14 (1), 28-37. doi:10.5550/sgia.181401.en.grz 


\begin{tabular}{|l|l|l|l|l|l|}
\hline \multirow{3}{*}{$\begin{array}{l}\text { Line player } \\
\text { Pivot }\end{array}$} & Count \% within & 4 & 9 & 8 & 21 \\
\cline { 2 - 6 } Centre back & Type of posture & $25,0 \%$ & $26,5 \%$ & $16,7 \%$ & $22,4 \%$ \\
\cline { 2 - 6 } & Count \% within & 1 & 5 & 4 & 10 \\
\cline { 2 - 6 } & Type of posture & $6,3 \%$ & $14,7 \%$ & $8,3 \%$ & $10,2 \%$ \\
\hline \multirow{2}{*}{ Total } & Count \% within & 16 & 34 & 48 & 98 \\
\cline { 2 - 6 } & Type of posture & $100,0 \%$ & $100,0 \%$ & $100,0 \%$ & $100,0 \%$ \\
\hline
\end{tabular}

There was no significant difference in the ratio of the player position relative to the type of posture (Monte Carlo method, $\mathrm{P}=0.192$ ).

Table 13 - Overview of respondents' postures and years of handball training

\begin{tabular}{|l|l|l|l|l|l|}
\hline & & & $\begin{array}{l}\text { Std. } \\
\text { Deviation }\end{array}$ & Minimum & Maximum \\
\hline Left-sided & 16 & 4,44 & 1,36 & 1 & 6 \\
Normal & 34 & 4,24 & 1,39 & 1 & 7 \\
Right-sided & 48 & 5,15 & 1,68 & 1 & 9 \\
Total & 98 & 4,71 & 1,58 & 1 & 9 \\
\hline
\end{tabular}

The number of years of training differed significantly between the types of scoliotic posture $(\mathrm{F}(2,97)=3,775 ; \mathrm{P}=0,026)$. Posthoc tests showed a significant difference between right-sided and normal posture (Posthoc Tukey test, $\mathrm{P}=0,026$ ), where subjects with rightsided scoliotic posture had spent significantly more years training handball compared to normal posture.

The mean value of training years was $4,71 \pm 1,5$ years. The minimum number of years of training was 3 , and the maximum number of years of training was 9 years. 


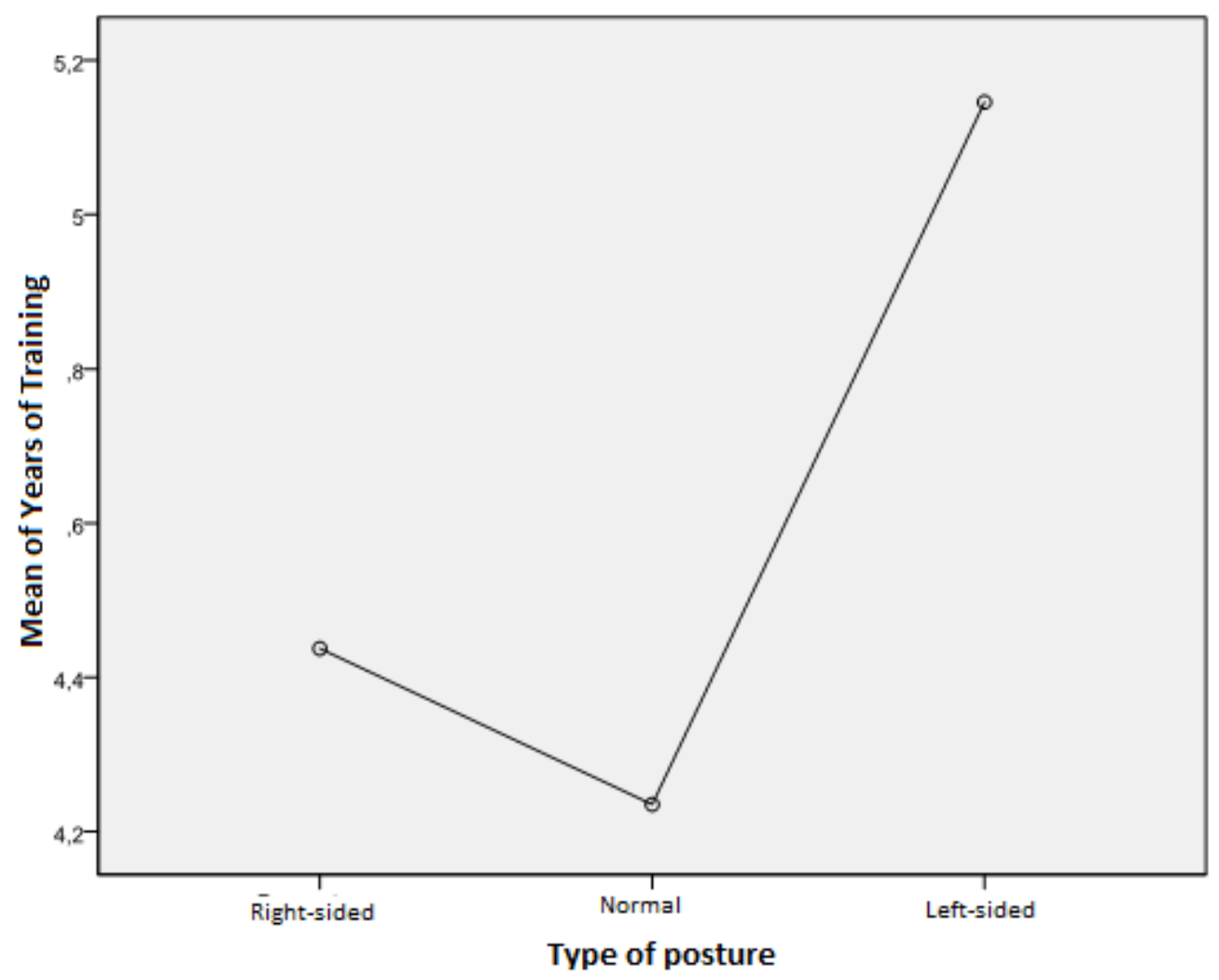

Figure 2 - Overview of respondents by type of posture and years of training

\section{DISCUSSION}

Dominant right-handed respondents had a significantly higher incidence of right-sided scoliotic posture than those with dominant left hand $\left(\chi^{2}\right.$ test $\left.=6,253 ; \mathrm{df}=2 ; \mathrm{P}=0,044\right)$. Leftsided scoliotic posture was found in 16 subjects, out of which $12(75,00 \%)$ right-handed, 4 $(25,0 \%)$ were left-handed. 34 respondents show normal body posture, of whom $31(91,2 \%)$ are the dominant right-handed respondents, and $3(8,8 \%)$ of the respondents with left hand. Right-sided scoliotic posture was proven in 48 respondents, $46(95,8 \%)$ right-handed and 2 $(4,2 \%)$ left-handed. The conclusion is that persons with a dominant right hand have significantly more frequent right-sided skolioic posture compared to those with dominant left hand, where this difference is not found to be statistically significant. In the general population, almost $90 \%$ of the people are right-handed (Incel, Ceceli, Durukan, Erdem and Yorgancioglu, 2002). Goldberg et al. (1990) found in right-handed respondents the connection between hand use and overcoming the right side of thoracic curve in adolescent idiopathic scoliosis. However, this connection was not confirmed in the left-handed children, it was found that the curvature direction of the spine in this group was randomly distributed. Hansgerd (1998) proved that sport in which specific stresses for the upper extremity are mostly single-sided, during growth can lead to changes in soft tissues and bones. The research conducted on professional tennis players showed hypertrophy of the upper arm bone on x-rays on the dominant hand, ie. the one that is more active in the sport. The difference in the cortical thickness of the bones of dominant and non-dominant hand is a response to exercise and increased physical effort (Jones, Priest, Hayes, Tichenor and Nagel, 1977). 
The ratio of the type of body posture with a player's position in handball showed that the highest number of players with right-sided scoliotic posture was in the left wing position $(33,3 \%)$ and the lowest at the right wing $(6,3 \%)$. The position with tha highest number of players with normal posture is the pivot $(26,5 \%)$, and the lowesr on the right back position $(5,9 \%)$. The left-sided scoliotic posture is the most common among the players in the right wing position $(31,3 \%)$, and not even one in the goalkeeper position. A statistically significant difference has not been demonstrated. Previous studies have shown that players in particular positions differ significantly from one another in some morphological parameters, particularly in body height and subcutaneous fat tissue (Chinn, Priest and Kent 1974; Hansgerd, Andreas, Gerd and Alfried-Krupp, 1998; Sporis, Èanaki and Barisic, 2007; Pieper, 1997). There were differences in body height between back and wing positions and the amount of body fat between the goalkeeper and other team players (Hansgerd, Andreas, Gerd and Alfried-Krupp, 1998; Pieper, 1997; Sporic, Èanaki and Barisic, 2007).

All of the above can be the reason for this distribution of body posturea in the handball players. The study showed that the years of training were in a positive correlation with the length of the hand (Spearman's rho $=0,288 ; \mathrm{P}=0,004)$. The difference in the length of the arm was in a positive correlation with the difference in the length of the hand (Spearman's rho $=0,317 ; \mathrm{P}=0,001$ ) as well as the difference in the upper arm circumference (Spearman's rho $=0,304 ; \mathrm{P}=0,002)$. The difference in the length of the hand was in a positive correlation with the difference in the upper arm circumference (Spearman's rho=0,523; $\mathrm{P}<0.001$ ). Fingers are the smallest, lightest parts of the motor apparatus, therefore they are the parts that can easily divert power of a ball, but at the same time, controlling the ball over the fingers is especially important for the accuracy of the various shots in handball. Types of scoliotic posture vary considerably according to the years of training handball $F(2,97)=3,775$; $\mathrm{P}=0,026)$. The index of left and right arm symmetry in the observed sizes (arm length, hand length and upper arm circumference) did not prove to be a significant difference with regard to the types of body postures in the frontal plane.

\section{CONCLUSION}

In this research, it has been determined that the greatest number of players with a right-sided scoliotic posture is in the left wing position and the lowest in the right wing position, and that the pivot playing position is the position with the highest number of players with normal posture, and the right-back position with the lowest. It has also been found that left-sided scoliotic posture is most common among the players in the right wing position, and not even one in the goalkeeper position. There is a significant difference between right-sided and normal body posture, where right-sided posture respondents have spent significantly more time practicing handball compared to those with normal posture, suggesting that this sport can be associated with the appearance of a scoliotic posture. 


\section{REFERENCE}

Aagaard, H., \& Jørgensen, U. (1996). Injuries in elite volleyball. Scand J Med Sci Sports, $6(4), 228-232$.

https://doi.org/10.1111/j.1600-0838.1996.tb00096.x

PMid:8896096

Chinn, C. J., Priest, J. D., \& Kent, B. E. (1974). Upper Extremity Range of Motion, Grip Strength, and Girth in Highly Skilled Tennis Players. Phys Ther, 54(5), 474-483. https://doi.org/10.1093/ptj/54.5.474

PMid:4423510

Goldberg, C. \& Dowling, F. (1990). Handedness and scoliosis convexity: a reappraisal. Spine Phila Pa, 15(2), 61-4.

https://doi.org/10.1097/00007632-199002000-00001

PMID:2326712

Hansgerd, P., Andreas, K., Gerd, Q., \& Alfried-Krupp, K. (1998). Muscular imbalances in elite handball players - practicconsequences with respect to the prevention of injuries. In H. J. Riehle, \& M. M. Vieten (Eds.), Proceedings II: 16 international symposium on biomechanics in sports (pp. 325-328). Konstanz, GER. University of Konstanz.

Hansgerd, P. (1998). Humeral Torsion in the Throwing Arm of Handball Players, Am. J. Sports Med. 26(2), 247-253.

https://doi.org/10.1177/03635465980260021501

PMid:9548119

Incel, N., Ceceli, E., Durukan, P., Erdem, H., \& Yorgancioglu, Z. (2002). Grip strength: effect of hand dominance. Singapore Med J. 43(5), 234-7. PMid:12188074

Janković, V., Marelić, N., \& Janković, G. (2003). Suvremeni model metodike treninga u školskom sportu. In V. Findak i K. Delija (Eds.), Zbornik radova, 12. Ljetna škola kineziologa Republike Hrvatske (pp. 147- 150). Rovinj, HR. Hrvatski kineziološki savez.

Jones, H., Priest, J., Hayes, E., Tichenor, C., \& Nagel, D. Humeral hypertrophy in response to exercise, J Bone Joint Surg Am 59(2), 204-208. PMid:845205

Kosinac, Z. (2002). Kineziterapija sustava za kretanje. Split, HR: Sveučilište u Splitu, Kineziološki fakultet.

Paušić, J. (2007). Konstrukcija i vrednovanje mjernih postupaka za procjenu tjelesnog držanja u dječaka od 10 do 13 godina. Doktorska disertacija. Kineziološki fakultet, Sveučilišta u Zagrebu.

Pieper, H. G. (1997). Humeral Torsion in Recurrent Shoulder Dislocation - A Radiological Comparison of 240 Stable and 300 Unstable Shoulders. Orthop. Trans 21(1), 102-103.

Sporiš, G., Ėanaki, M., \& Barišić, V. Morphological differences of elite Croatian female soccer players according to them position. Hrvatski sportskomedicinski vjesnik, 22(2), 91-96.

Theologis, T. N., Fairbank, J.C., Turner-Smith, A.R., Pantayopoulos, T. (1997). Early detection of progression in adolescent idiopathic scoliosis by measurement of changes in back shape with the integrated shape imaging system scanner. Spine 22(11), 223-7.

https://doi.org/10.1097/00007632-199706010-00010

Grbavac, V., Rezić, M., \& Zovko, I. Č. (2018). Connection between body posture indicators and dominant hand with scoliotic body posture in handball players. Sportlogia, 14 (1), 28-37. doi:10.5550/sgia.181401.en.grz 


\section{SAŽETAK}

Suvremeni način života uzrok je sve veće pojave nepravilnih tjelesnih držanja kod djece i adolescenata. Kod sportaša nepravilna tjelesna držanja mogu izazvati brojne kronične zdravstvene probleme i ozljede koje utječu na njihovu uspješnost u sportu. Rukometnu igru karakterizira dinamičnost i pokretljivost, uz stalne i brze promjene položaja tijela i elemenata tehnike. Zbog određenih karakteristika rukometa kao sporta (dijelovi tehnike koji su asimetrični zbog igranja jednom rukom) postoji osnovana sumnja, da su rukometaši izloženi faktorima koji mogu uzrokovati razvoj posturalnih deformiteta. Cilj istraživanja bio je ispitati je li skoliotično držanje česta pojava u adolescenata koji treniraju rukomet, te postoji li povezanost između relevantnih pokazatelja nepravilnog držanja i dominantne ruke sa skoliotičnim tjelesnim držanjem kod rukometaša. Istraživanje je provedeno na uzorku 98 adolescenata u dobi od 13-18 godina koji su uključeni u trenažni proces preko tri godine, a testirani su kliničkim Adamsovim testom pretklona. Za utvrđivanje tipova tjelesnog držanja primijenjen je posteriorni pregled. Uzorak varijabli za procjenu tjelesnog držanja sadržavao je numeričke vrijednosti osam referentnih točaka u posteriornom pregledu. Za utvrđivanje razlika između skupina u varijablama upitnika, te kod utvrđivanja razlike između ispitanika kod varijabli dobivenih iz upitnika, korišten je Hi kvadrat test, te je određena kontingencijska tablica s frekvencijama i postotcima. Ustanovljena je značajna razlika između desnostranog i normalnog tjelesnog držanja, gdje su ispitanici s desnostranim držanjem značajno više godina proveli trenirajući rukomet u odnosu na one sa normalnim držanjem, što navodi na zaključak kako ovaj sport može da se povezuje uz pojavu skoliotičnog držanja.

Ključne riječi: držanje tijela, dominantna ruka, skoliotično držanje, rukomet

Received: 26.03.2018.

Approved: 26.05.2018.

Correspondence:

Vedrana Grbavac

University Clinical Hospital in Mostar vgrbavac01@gmail.com

Grbavac, V., Rezić, M., \& Zovko, I. Č. (2018). Connection between body posture indicators and dominant hand with scoliotic body posture in handball players. Sportlogia, 14 (1), 28-37. doi:10.5550/sgia.181401.en.grz 